JISIP: Jurnal Ilmu Sosial dan Ilmu Politik

ISSN. 2442-6962

Vol. 9 No. 1 (2020)

\title{
PENGELOLAAN PENGADUAN MASYARAKAT DALAM UPAYA MENINGKATKAN KUALITAS PELAYANAN PUBLIK
}

\author{
Hiasinta Sabeni, Emei Dwinanarhati Setiamandani \\ Program Studi Ilmu Administrasi Publik, Universitas Tribhuwana Tunggadewi \\ Email: sabenihiasinta97@gmail.com
}

\begin{abstract}
Abstrak: Pelayanan publik merupakan sebuah tolak ukur kinerja pemerintah yang bersentuhan langsung dengan kebutuhan masyarakat pada umumnya. Melalui penyelenggaraan pelayanan publik yang dilakukan pemerintah, masyarakat dapat mengukur standar dan kualitas pelayanan yang diberikan pemerintah terhadap masyarakat sebagai obyek kebijakan publik. Sehingga sebagai wujud dari penyelenggaraan Negara yang demokrasi, maka masyarakat memiliki hak untuk menyampaikan pengaduaan terhadap nilai (value) dari kualitas pelayanan publik yang diberikan oleh pemerintah. Metode yang digunakan dalam penelitian ini merupakan jenis penelitian kualitatif. Lokasi yang dipilih untuk melihat obyektifitas masalah yang sedang diteliti di Dinas Kependudukan Dan Pencatatan Sipil Kota Malang. Dengan menggunakan metode pengumpulan data melalui purposive sampling peneliti memilih tiga informan diantaranya, kasubag program dan pelaporan, kasubag umum dan kepegawaian dan masyarakat. Pengumpulan data penelitan menggunakan prinsip triangulasi teknik melalui wawancara, observasi dan dokumentasi, yang kemudian hasilnya akan diolah dan dianalisa sesuai dengan konsep yang sistematis yakni proses reduksi data (reduction), penyajian data (display) dan penarikan kesimpulan atau verifikasi data (verivication).
\end{abstract}

Kata Kunci: Kualiatas Pelayanan Publik, Kinerja Pemerintah

Abstract: Public service is a benchmark of government performance that is in direct contact with the needs of the general public. Through the implementation of public services conducted by the government, the public can measure the standards and quality of services provided by the government to the community as objects of public policy. So that as a manifestation of the implementation of a democratic State, the community has the right to convey adherence to the value of the quality of public services provided by the government. The method used in this study is a type of qualitative research. The location chosen to see the objectivity of the problem being studied at the Malang City Population and Civil Registry Office. By using the method of data collection through purposive sampling the researchers selected three informants including, the Head of Program and Reporting, the Head of the General Section and the staff and the community. Research data collection uses the principle of technical triangulation through interviews, observations and documentation, which will then be processed and analyzed in accordance with a systematic concept of the process of data reduction (display), presentation of data (display) and drawing conclusions or verification of data (verivication).

Keywords: Quality of Public Services, government performance 
JISIP: Jurnal Ilmu Sosial dan Ilmu Politik

ISSN. 2442-6962

Vol. 9 No. 1 (2020)

\section{PENDAHULUAN}

Pelayan publik menjadi suatu tolak ukur kinerja pemerintah yang paling kasat mata, masyarakat dapat langsung menilai kinerja pemerintahan berdasarkan kualitas pelayanan publik yang diterima karena kualitas pelayanan publik menjadi kepentingan banyak orang dan dampaknya langsung dirasakan masyarakat dari semua kalangan, dalam hal ini pelayanan publik juga merupakan tugas yang paling penting dimiliki oleh aparatur pemerintahan sebagai abdi negara dan abdi masyarakat penyelengaraan pelayanan publik perlu memperhatikan dan menerapkan prinsip, standar, pola penyelenggaraan dan biaya, supaya semua kebutuhan dan kepentingan pihak yang membutuhkan pelayanan tersebut. (Zaenal Mukarom 2018:79)

Undang-Undang Republik Indonesia Nomor 25 Tahun 2009 Tentang Pelayanan Publik, Undang-Undang ini menjadi acuan/pendoman pemerintahan pusat maupun pemerintah daerah di Indonesia dalam menjalankan ativitas pemerintah demi mewujudkan terciptanya pelayanan publik yang baik dan sesuai dengan apa yang dibutuhkan masyarakat Pelayanan publik dapat diartikan sebagai sebuah kegiatan dimana dapat memenuhi keperluan masyarakat. Kedua, aspek kepentingan penerima pelayanan public, sebaliknya (costomers).

Dalam Undang-Undang Nomor 25 Tahun 2009 Tentang Pelayanan Publik dijelaskan bahwa "kegiatan atau rangkain kegiatan dalam rangka pemenuhan kebutuhan pelayanan, hal ini merupakan bentuk pelayanan atas barang, jasa, dan/atau pelayanan administratif yang disedia oleh penyelenggara pelayanan publik". Karena itu dalam pelayanan, masyarakat berhak mengadu dengan apa yang mereka rasa dan dapatkan setelah mereka menerima pelayanan yang buruk atau kurang baik dari penyelenggaraan pelayanan itu sendiri.

Dilihat pada masalalu dan sekarang Negara dalam sistem pemerintahan menjadi tumpuan pelayanan warga Negara dalam memperoleh jaminan atas hak-haknya dalam memperoleh pelayanan. Pelayanan publik yang diselenggarakan oleh pemerintah seringkali mengabaikan dan mengecewakan rakyatnya, Untuk memperoleh pelayanan yang sederhana saja masyarakat seringkali dihadapkan dengan proses yang berbelit-belit bahkan antrian yang cukup panjang dan mendapatkan waktu yang cukup lama sehingga masyarakat merasa tidah betah menunggu dalam proses pelayanan oleh sebab itu pengaduan masyarakat sangat penting bagi pemerintah untuk melihat seberapa besar keberhasilan dalam melaksanakan kegiatan.

Pengaduan masyarakat merupakan elemen penting dalam setiap intansi yang melakukan penyelenggara pelayan publik, karena pengaduan masyarakat bertujuan untuk memperbaiki dari kekurangan dari kegiatan yang sudah dilaksanakan. Untuk menjamin kualitas pelayanan publik yang terus menerus dan berkelanjutan diperlukan manajemen pengelolaan pengaduan yang memiliki 2 (dua) aspek yang dilihat dari pengaduan ini yaitu: pertama, aspek kepentingan penyelenggara (service provider) Dalam Peraturan Presiden 
JISIP: Jurnal Ilmu Sosial dan Ilmu Politik

ISSN. 2442-6962

Vol. 9 No. 1 (2020)

Republik Indonesia Nomor 76 tahun 2013 mengatakan pengelolaan pengaduan pelayanan publik yang selanjutnya disebut pengelola adalah pejabat, pegawai atau orang yang ditugaskan oleh penyelenggara untuk mengelola pengaduan masyarakat pada setiap penyelenggara pelayanan publik.

Pengaduan merupakan sarana untuk memperbaiki kualitas penyelenggara pelayanan publik sebaiknya dari aspek kepentingan penerima pelayanan dan masyarakat merupakan sarana menyampaikan pengaduan untuk mendapatkan pelayanan yang lebih baik dengan demikian pemerintah perlu melihat dari kualitas pelayanan yang diberikan penyelenggara terhadap masyarakat merupakan sebuah aturan yang dibuat pemerintah untuk mengatur agar kehidupan bersama berjalan dengan baik dan memberi kenyamanan bagi setiap warga Negara serta merupakan sebagai pelayanan masyarakat, dalam memenuhi kebutuhan serta mewujudkan dan menyediakan barang dan jasa yang berkualitas serta memiliki nilai yang berguna bagi masyarakat. (http://menpan.go.id. tingkat pelayanan publik melalui pengaduan) diakses pada 26 november 2019.

Jika ditelusuri masih banyak ditemukan masalah dalam penyelenggara pelayanan publik merupakan persyaratan-persyaratan dokumen yang masih terdapatnya kekurangan informasi yang didapatkan masyarakat terkait persyaratan-persyaratan dokumen yang diselenggarankan oleh intansi salah satunya pembuatan kartu keluarga karena pada saat ini kartu keluarga yang sering diajukan masyarakat untuk diperbaharui maupun yang baru buat, masih sanggat jarang melakukan atau mengadakan sosialisasi baik didesa maupun dikelurahan yang berkaitan dengan kebutuhan masyarakat dalam persyaratan pembuatan dokumen yang mereka ingin ajukan.

Maka dari itu perlu adanya suatu sarana pengaduan disetiap kelurahan untuk mendapatkan pengaduan dari pengadu ataupun penerima pelayanan tentang persyaratan yang ingin masyarakat ajukan, dalam mengelola pengaduan dilihat dari SOP pelayanan publik itu sendiri. Untuk meningkatan kualitas pelayanan publik dapat dilakukan melalui penyelesaian pengaduan yang cepat dari penyedia layanan dalam hal ini intansi pemerintahan baik dipusat maupun didaerah. Segala bentuk kritik maupun aduan yang disampaikan masyarakat pada suatu intansi merupakan sebuah koreksi untuk perbaikan pelayanan itu sendiri kedepanya. Agar kualitas pelayanan publik semakin baik, para penyedia pelayanan harus menangani serta menindaklanjuti segala bentuk aduan dari masyarakat Namun Sejauh ini masih belum maksimal bagaimana tindakan pemerintah dalam meningkatkan kualitas pelayanan dengan mengadakan sarana pemgaduan bagi masyarakat yang merasa dalam penyelenggaraan pelayanan yang masih belum baik atau masih belum memberi efek yang baik (http://menpan.go.id.) tingkat pelayanan publik melalui pengaduan) diakses pada 26 november 2019.

Berdasarkan fakta yang didapatkan di Dinas Kependudukan dan Catatan Sipil Kota Malang pada tahun 2016. (MalangVoice, Malang Raya selasa, 26 april 2016) dari sejumlah penyempurnaan, Dispendukcapil ternyata menemukan banyak data yang tidak sesuai 
JISIP: Jurnal Ilmu Sosial dan Ilmu Politik

ISSN. 2442-6962

Vol. 9 No. 1 (2020)

dengan kondisi nyata masyarakat Kota Malang salah satunya di beberapa KTP dan KK banyak menggunakan nama panggilan dan nama kecil Sekertaris Dispendukcapil mengukgapkan "kami sebernya ingin mensosialisaikan kebijakan kependudukan dan pencatatan sipil dalam Peraturan Mendagri Nomor 8 dan 9 Tahun 2016. Nah ternyata kami menemukan banyak persoalan" ungkapnya pada Malangvoice.com Menurut Arsan, banyak didapati data yang tercamtum di Dispendukcapil salah satu sengaja dipalsukan. Dibeberapa data KTP dan KK, "kita membutuhkan waktu yang lumayan lama untuk pencocokan ini, karena pemdes perlu aktif mensosialisai ini. Kalau tidak segera diselesaikan, maka aka ada persoalan dimasa depan, misalnya jika kita ingin membuat paspor untuk keperluan keluar negri, atau mengurus hak-hak lainnya kita perlu persyaratan untuk mencetak hal tersebut "papar Arsan. (Sumber.Malangvoice.com selasa, 26 april 2016).

Pentingnya mengadakan sarana pengelolaan pengaduan, bertujuan untuk memperbaiki kekurangan dan kesalahan dari pemberi pelayanan dengan berfokus mengadakan sarana pengelolaan pengaduan maupun membantu penyelenggara dalam memperbaiki kekurangan yang diberikan dalam pelaksanaan pelayanan sehingga mampu mengurangi masalah yang ditemui dalam pelayanan agar mampu menjadikan pelayanan yang lebih baik lagi. Dengan demikian apa yang diselenggarakan oleh penyelenggara pelayanan bisa diperbaiki melewati sarana pengaduan di Dinas kependudukan dan catatan sipil Kota Malang demi menunjang kesejahtreaan masyarakat yang adil dan makmur serta menuju pelayanan yang dimiliki kualitas pelayanan yang baik dengan mengadakan sarana pengelolaan pengaduan. Dilihat dari masalah diatas tentang persyaratan administrasi pelayanan salah satu contoh jenis pembuatan Kartu Keluarga, Masyarakat masih harus mendatangi kantor desa atau pun kelurahan langsung untuk menayakan persyaratan yang harus dilampirkan dalam mengurus dokumen yang ingin mereka ajukan dengan adanya sarana pengaduan masyarakat lebih mudah menyampaikan keluhan mereka tentang pelayanan yang mereka dapatkan.

\section{METODE PENELITIAN}

Jenis penelitian yang digunakan dalam penelitian ini adalah penelitian kualitatif, menurut Sugiyono (2016:1) metode penelitian kualitatif adalah metode penelitian yang digunakan untuk meneliti pada kondisi obyek yang alamiah, (sebagai lawanya adalah eksprimen) dimana peneliti sebagai instrument kunci, teknik pengumpulan data dilakukan secara triangulasi (gabungan), analisis data bersifat induktif, dan hasil penelitian kualitatif lebih menekankan makna dari pada generalisasi. Oleh karena itu penelitian ingin memahami dan menganalisis mengenai Pengelolaan Pengaduan Masyarakat dalam upaya Meningkatkan Kualitas Pelayanan Publik. Penelitian ini dilaksanakan di Dinas Kependudukan dan Pencatatan Sipil Kota Malang, Fokus yang akan diteliti dalam penelitian ini adalah pengelolaan pengaduan pelayanan publik sebagai berikut:

a. Tempat/Ruangan 
JISIP: Jurnal Ilmu Sosial dan Ilmu Politik

ISSN. 2442-6962

Vol. 9 No. 1 (2020)

b. Kotak Pengaduan

c. Formulir Pengaduan dan alat tulis

d. Perangakat Teknologi Informasi Komunikasi (TIK)

Teknik pengumpulan data yang dilakukan adalah menggunakan triangulasi teknik yakni wawancara, observasi dan dokumentasi dengan analisa data menggunakan metode reduction, data display dan penarikan kesimpulan atau verification.

\section{HASIL PENELITIAN DAN PEMBAHASAN}

\section{Pengelolaan pengaduan Masyarakat Dalam Meningkatkan Kualitas Pelayanan}

Dari hasil wawancara, observasi dan dokumentasi yang diperoleh dari penyajian data, secara mekanisme terdapat dua jenis pengaduan yakni pengaduan secara langsung dan tidak langsung. Pengaduan secara langsung daat dilakukan melalui pimpinan atau tim pengelolaan pengaduan dengan menggunakan kotak saran atau formulir pengaduan serta bisa dilalukan dengan cara menyampaikan secara lisan terhadap pimpinan atau perangkat terkait. Sedangkan pengaduan secara tidak langsung dispendukcapil menggunakan media sosial sebagai sarana pendukung untuk mewadahi masyarakat dalam menyampaikan pengaduan secara cepat terhadap perilaku, kinerja atau pelayanan yang dilakukan oleh dispendukcapil, diantaranya menggunakan email atau whatsapp. Selanjutnya pengaduan yang disampaikan secra langsung baik menggunkan kotak saran, formulir ataupun langsung secara lisan dan secara tidak langsung menggunkan media sosial seerti melalui email atau whatsapp akan ditindak lanjuti dengan pimpinan pada saat rapat evaluasi dinas kependudukan dan pencatatan sipil kota malang. Hasil dari evaluasi inilah yang akan menjadi tolak ukur dispendukcail untuk melakukan perubahan sebagai bahan perbaikan kearah yang lebih baik.

Sarana pengelolaan pengaduan menjadi pisau analisis yang digunakan dalam menganalisis pengelolaan pengaduan masyarakat di Dinas kependudukan dan Pencatatan Sipil Kota Malang, berdasarkan masalah yang difokuskan pada sarana pengelolaan pengaduan pelayanan publik peneliti menggunakan penelitian menggunakan Undangundang Nomor 24 Tahun 2014 ayat 12 Sarana pengelolaan pengaduan pelayanan publik dapat berupa,
a. Tempat/Ruangan
b. Kotak pengaduan
c. Formulir pengaduan dan alat tulis
d. Perangkat Teknologi Informasi Komunikasi (TIK)

Undang-Undang Nomor 25 Tahun 2009 "tentang pelayanan Publik" bahwa pelayanan publik merupakan kegiatan atau rangkaian dalam rangka memenuhan kebutuhan pelayanan sesuai dengan peraturan perundang-undangan bagi setiap warga negara dan penduduk atas barang, jasa dan/atau pelayanan administratif yang disediakan oleh 
JISIP: Jurnal Ilmu Sosial dan Ilmu Politik

ISSN. 2442-6962

Vol. 9 No. 1 (2020)

penyelenggara pelayanan publik serta didukung dengan Undang-Undang Nomor 25 tahun 2014 Tentang Pendoman Penyelenggaraan Pengelolaan Pengaduan pelayanan Publik sehingga mampu membantu memperbaiki pelayanan. Dalam pelaksanaan pengelolaan pengaduan unutuk mempermudah pengaduan dalam pengelolaan pengaduan sangat membantu dalam menerima keluhan yang disampaikan masyarakat.

Menurut Undang-Undang Nomor 25 Tahun 2014 Tentang pendoman Penyelenggara Pengelolaan Pengaduan Pelayan Publik Bab III yaitu mengenai mekanisme pengelolaan pengaduan dalam penerimaan pengaduan melalui alur yang umum, peyelenggara wajib menerima pengaduan sesuai dengan kebijakan "no wrong door policy", yaitu menerima pengaduan dari manapun dan jenis apaun serta menjamin bahwa pengaduan akan disalurkan kepada penyelanggara pelayanan publik yang berwewenang menangani. Penerimaan pengaduan melimputi, a) pengaduan secara langsung dimana pengaduan disampaikan secara lisan kepada penyelenggara. b). Pengaduan secara tidak langsung dimana pengaduan disampaikan melalui, kotak pengaduan, surat, Teknologi Komunikasi.

Dalam sarana pengelolaan pemgaduan yaitu merupakan tempat/ruangan, kotak pengaduan, formulir pengaduan dan perangkat teknologi informasi komunikasi merupakan sarana untuk membantu pengelolaan pengaduan dan penerimaan pengaduan, sarana pengaduan yang sudah disedikan di dispendukcapil yaitu tempat/ruangan yag sudah dilengkapi sebuah komputer khusus serta sarana pengaduan melalui perangkat teknologi informasi komunkasi yaitu melalui whatsapp dan dengan adanya sarana pengelolaan pengaduan atau keluhan yang disampaikan masyarakat, dengan adanyanya sarana pengelolaan pengaduan yang beuruk menjadi lebih baik. Dalam pengelolaan pengaduan masyarakat dalam meningkatkan kualitas pelayanan petugas akan mengadakan rapat sebulan sekali bersama.

Hal ini seraras dengan penelitian terdahulu yang dilakukan oleh Mursalim 2018, yang bejudul analisis manajemen pengaduan sistem layanan aspirasi pengaduan online ralyat LAPOR) di Dinas Komunikasi dan informatika pemerintah Kota bandung dengan hasil penelitian yang menunjukan adanya layanan aspirasi secara online rakyat bertujaun untuk mempermudah masyarakat sebagai tempat pengaduan dalam mengeluarkan aspirasi ataupun keluhan terhadap kinerja Kota Bandung, pengelolaan sistem LAPOR di Dinas komunikasi dan informatika pemerintah kota bandung belum terisolasi secra merata dikarangan masyarakat sendiri dilihat dari masih banyaknya masyarakat yang belum menggunakan aplikai LAPOR.

Dinas keendudukan dan pencatatan siil kota malang telah menerapkan sistem yang berbasis informatika seerti enggunaan media sosial yakni email dan whasapp serta website yang sementara dikerjakan atau diproses oleh disendukcail kota malang. pada era perkembangan globalisasi saat ini memang masyarakat dituntut untuk selalu modern dalam mengikuti perkembangan zaman sehingga enggunaan teknologi oleh emerintah untuk memermudah elayanan yang baik terhada masyarakat sudah sangat layak untuk dijalankan. 
JISIP: Jurnal Ilmu Sosial dan Ilmu Politik

ISSN. 2442-6962

Vol. 9 No. 1 (2020)

Sumber daya teknologi memsng erlu ditunjang dengan sumberdaya manusia yang baik, agar teknologi yang dilakukan untuk memermudah segala macam kegiatan manusia daat berjalan dengan baik. Namun disis lain enggunaan teknologi dinegara erkembang terkadang tidak sesuai dengan kondisi atau situasi yang dialami oleh negara tersebut, seerti halnya dalam ruang lingku yang lebih kecil seerti dinas keendudukan dan encatatan siil kota malang ini. Dimana enggunaan teknologi informasi dan komunikasi dengan berbasis media sosial seerti email dan whatsapp serta website ini harus seraras dengan kondisi masyarakat dengan tingkat sumber daya yang dimiliki. Masyarakat yang ada dilingkungan malang secara umum harus mengetahui media sosial yang dimiliki oleh dinas keendudukan dan encatatan siil kota malang, agar masyarakat daat menggunakan sarana yang disediakan dengan baik dan benar. Oleh karena itu apabila terdapat masyarakat yang memiliki kualitas sumber daya manusia yang kurang memadai, maka penggunaan sumber daya teknologi informasi dan komunikasi dengan menggunkan email dan whatsapp oleh masyarakat masih sulit dilaksanakan dengan baik.

Dalam melaksanakan pelayanan publik pemerintah melalui segala fasilitas yang dimiliki harus memberikan rasa kepuasan terhadap masyarakat, karena itu melalui pengaduan masyarakat baik secara langsung akan berpengaruh terhadap kualitas pelayanan publik oleh pemerintah. Untuk menyediakan kualitas pelayanan publik yang dimaksud dipertegas oleh Ibrahim dalam Hardiansah 2019: 43 yang menjelaskan bahwa kualitas pelayanan publik merupakan suatu kondisi dinamis yang berhubungan dengan produk, jasa, manusia proses dan lingkungan dimana penilaian kualitasnya ditentukan pada saat terjadi pemberian pelayanan publik tersebut. pemerintah dispendukcapil kota malang dalam menyediakan kualitas pelayanan publik telah melakukan pelayanan sesuai dengan standar oprasional dalam bentuk pelayanan pengaduan secara langsung dan tidak langsung. Dengan sistem yang diterapkan dispendukcapil sebagai sebuah upaya untuk meningkatkan kualitas pelayanan publik maka perlu menerima maasukan kritik dan saran dari masyarakat sebagai pihak yang menerima pelayanan publik untuk mengarahkan pelayanan yang dilakukan oleh pemerintah dapat berjalan dengan baik sehingga mampu mendorong inovasi-inovasi pelayanan di dispendukcapil.

Selanjutnya menurut pasolong 2017: mengatakan ada dasarnya manajemen merupakan instansi pemerintah. Jadi manajemen publik merupakan bagaimana mengatur kepentingan publik atau orang banyak. Kualitas pelayanan publik dalam hal ini untuk meningkatkan kepuasan masyarakat dalam menerima pelayanan publik dapat berjalan dengan baik apabila instansi pemerintah sebagai penyelenggara pemerintahan harus mampu memanajemenkan pelayanan publik untuk dapat memenuhi kepentingan publik atau orang banyak secara universal. Karena itu dengan menyediakan ruang bagi masyarakat untuk menyampaikan aspirasinya melalui pengaduan baik secara langsung dan tidak langsung dapat mendorong perbaikan kualitas dari manajemen pelayanan publik yang diselenggarakan oleh dispendukcapil. 
JISIP: Jurnal Ilmu Sosial dan Ilmu Politik

ISSN. 2442-6962

Vol. 9 No. 1 (2020)

Selanjut secara teknis Kepala Dinas Dispendukcapil untuk menindak lanjuti atau mengevaluasi pelaporan ataupun keluhan yang disampaikan masyarakat melalui sarana pengelolaan yang sudah disedikan yaitu tempat/ruangan yang sudah dapat sebuah komputer khusus untuk pengaduan serta melalui teknologi informasi komunikasi melalui whapsapp yang juga sudah disediakan dispendukcapil dari bagian program dan pelaporan dengan demikian masyarakat dengan mudah untuk menyampaikan pengaduan, pengaduan yang sudah disampaikan melalui sarana pengaduan di print dan dilihat keluhan masyarakat yang lebih banyak tidak puas terhadap pelayanan yang diterima dari bagian-bagian lebih banyak akan diberikan arahan dan dikontrol sesuai hasil rapat dan evaluasi akan digunakan sebagai bahan perbaikan pelayanan publik serta akan ditindak lanjuti sehingga pelayanan kedepanya yang diberikan akan lebih baik. mekanisme dalam pengelolaan pengaduan.

Masyarakat melakukan pengaduan lewat sarana dalam pengelolaan pengaduan yang sudah disediakan, penyelenggara mancetak pengaduan yang sudah disampaikan masyarakat melalui sarana pengaduan penyelenggara melakukan pelaporan atau evaluasi bersama kepala Dinas. Hasil dari evaluasi dilaksankan dan dipantau secara rutin demi kenyaman dan perbaikan pelayanan.

Tanggapan masyarakat setelah memberikan pengaduan/keluhan mereka merasa sangat lebih baik dengan pelayanan yang mereka terima setelah mereka memberikan pengaduan kerena dengan melapor pelayanan yang sebelunya mereka merasakan tidak baik dan pada saat mereka sudah memberikan pengaduan pelayanan yang dulu mereka terima tidak memuaskan dan pada saat mereka menerima pelayanan selanjutnya masyarakat akan mendapat pelayanan yang lebih bakik dari sebelumya. Dispendukcapil Kota malang selain sarana pengaduan yang sudah berfungsi pada saat berlangsunnya sekarang bagian program dan pelopran akan meluncurkan sarana pengaduan tambahan melalui wabsite resmi dan menambahkan kotak pengaduan.

\section{Faktor Pendukung dan Penghambat sarana Pengelolaan pengaduan dalam mneingkatkan Kualitas Pelayanan}

tempat/ruanga pengaduan yang sudah disedikan, dengan ini sangat mendukung program pelaksanaan pengelolaan pengaduan masyarakat dalam meningkatkan kualitas pelayanan meskipun ada beberapa mekanisme yang tidak di adakan sebagaimana dalam Undang-Undang Nomor 24 tahun 2014 Tentang pendoman penyelenggaraan pengelolaan pengaduan pelayanan publik secara Nasional ayat 1" pelayanan publik adalah kegiatan atau rangkaian kegiatan dalam rangka pemenuhan hak dasr pelayanan sesuai denganperaturan perundang-undangan bagi setiap warga negara dan pendudukan ats barang jasa dan/atau pelayanan administratif yang diselenggarakan oleh penyelenggara pelayan publik "serta ayat 12 " sarana pengaduan adalah tempat atau ruangan dan segala kelangakapnanya yang disediakan secara khusus untuk menerima pengaduan dari pengadu atu penerima pelayanan". 
JISIP: Jurnal Ilmu Sosial dan Ilmu Politik

ISSN. 2442-6962

Vol. 9 No. 1 (2020)

Faktor yang mendukung dalam pengelolaan pengaduan merupakan sarana atau tempat serta ruangan pengelolaan pengaduan oleh pemerintah intansi tersebut sudah baik serta dengan adanya pengaduan dari masyarakat pemerintah atau pengaduan pelayanan bisa memperbaiki pelayanan yang kurang memuaskan masyarkat serta akan memperbaiki kualitas pelayanan sehingga memiliki kualitas yang lebih baik masyarakat juga bisa merasakan pelaanan yang lebih nyaman, berkualitas dan memuaskan serta dalam pengelolaanya petugas melakukan evalusi setiap sebulan sekali dalam melihat pengaduan yang sudah disampaikan masyarakat melalui sarana yang yang sudah disediakan di dispendukcapil.

Sedangkan faktor penghambat dalam pelaksanaan pengaduan yaitu perangkat teknologi informasi komunikasi (TIK) tidak tidak tersedianya kotak pengaduan dan formulir pengaduan serta lambatnya respon dari petugas dalam menanggapi setiap keluhan masyarakat yang disampaikan masyarakat pada kantor Dinas Kependudukan dan pencatatan Sipil Kota Malang masyarakat sebagi penerima pelayanan atau dalam memberikan pengaduan ataupun keluhan dan tidak semua masyarakat bisa menggunakan alat teknologi dan masih kurangnya kesadaran masyarakat memanfaatkan fasilitas melalui sarana tersebut serta sarana melaui wabsite karena di Dinas kependudukan dan Pencatatan Sipil Kota Malang sendiri belum meliki wabsite resmi.

Dengan demikian adanya sarana teknologi informasi komunikasi (TIK) dan pelayanan pengaduan secara langsung mampu membantu masyarakat dalam memberikan keluhan terhadap penyelenggara pelayanan, pelayanan yang baik, cepat dan berkualitas serta bisa menerima keluhan atau pengaduan dari masyarakat melalui teknologi informasi dan komunikasi tersebut lebih mempermudhkan pemerintah untuk pengelolaan pelayanan serta pengaduan dari masyarakat,dengan adanya teknologi informasi dan komunikasi, harapan masyarakat sebgai pengguna pelayanan mamupun mencapi tujuan untuk mensejaterakan masyarakat.

\section{KESIMPULAN}

Sarana pengelolaan pengaduan oleh dinas Kependudukan dan Pencatatan Sipil Kota Malang belum berjalan dengan maksimal hal ini dikarenakan masih belum memenuhi standar sarana pengelolaan pengaduan sebagai berikut sarana pengelolaan pengaduan pelayanan publik dapat berupa Tempat/Ruangan, Kotak pengaduan, formulir pengaduan dan alat tulis, perangkat Teknologi Informasi Komunikasi (TIK) Undang-Undang Nomor 24 Tahun 2014 tentang Pendoman Penyelenggara Pengelolaan Pengaduan Pelayanan Publik secara Nasional serta Undang-Undang Nomor 25 Tatun 2009 Tentang Pelayanan Publik

Faktor pendukung dan penghambat dalam pengelolaan pengaduan masyarakat dalam meningkatkan kualitas pelayanan oleh Dinas Kependudukan dan Pecatatn Sipil Kota Malang yaitu: dari Faktor pendukungnya sudah terdapat sarana pengaduan yang disedikan 
JISIP: Jurnal Ilmu Sosial dan Ilmu Politik

ISSN. 2442-6962

Vol. 9 No. 1 (2020)

oleh Knator Dinas Kependudukan dan Pncatatan Sipil Kota Malang. Sedangkan faktor penghambatnya yaitu: perangkat teknologi informasi (TIK) melalui wabsite masih belum terealisasikan,lambatnya respon dari petugas penanganan pengaduan.

\section{DAFTAR PUSTAKA}

Bambang Irawan, 2017. Analisis Pelaksanaan Pengaduan Masyarakat. Universitas Mulawarman Samarinda. (https://e-journals.unmul.ac.id) diakses pada tanggal 10 november 2019.

Cahyo Sasmito, 2018. Madani. Jurnal Politik dan Sosial Kemasyarakatan. Volume 10. Nomor 2

Harbani, Pasolong. 2017. Teori Administrasi Publik. Bandung: Alfabeta

Hardiyansyah. 2017. Manajemen dan pengembangan organisasi publik. Yogyakarta: Gave Media

Humas menpanrb 04 oktober 2018. Kementrian pendayagunaan aparatur Negara dan refornasi birokrasi, tingkat pelayanan publi melalui penanganan pengaduan, (online), (http://www.menpan.go.id) diakses pada tanggal 26 november 2019.

Moleong. 2016. Metodologi Penelitian Kualitatif. Bandung: PT. Remaja Rosdakarya.

Mukarom dan Laksana. 2015. Manajemen pelayan publik. Bandung CV Pustaka Setia.

Peraturan Presiden Republik Indonesia Nomor 76 Tahun 2013 Pengelolaan Pengaduan Pelayanan Publik.

Siti Widharetno Mursalim, 2018. Analisis Manajemen Pengaduan Sistem Layanan Aspirasi Pengaduan Online Rakyat (LAPOR). STIA-Lembaga Administrasi Negara Bandung. (https://jia.stialanbandung.ac.id) diakses pada tanggal 2 november 2019.

Sugiyona. 2017 Metode Penelitian Kualitatif. Edisi ke-3. Bandung: Alfabeta

Sugiyono. 2015. Metode penelitia pendekatan kualitatif, kualitatif dan R\&D. Bandung: Alfabeta

Thoha, Miftah. 1997. Pembinaan Organisasi Diagonesa dan Intervensi Jakarta: Raja Grafindo

Undang-Undang Nomor 24 Tahun 2014 tentang pendoman penyelenggaraan pengelolaan pengaduan pelayana publik.

Undang-Undang Republik Indonesia Nomor 25 Tahun 2009 Tentang Pelayanan Publik.

Zaenal Mukarom \& Muhibudin Laksana. 2018. Manajemen Pelayanan Publik. Bandung: CV Pustaka Setia 